\title{
ЭКОЛОГО-ГИДРОГЕОХИМИЧЕСКАЯ ОЦЕНКА СОСТОЯНИЯ НЕОГЕН-ЧЕТВЕРТИЧНОГО ВОДОНОСНОГО КОМПЛЕКСА ЮГО-ВОСТОЧНОЙ ЧАСТИ ГОРОДА ВОРОНЕЖА
}

\author{
Д. А. Белозеров, А. С. Летникова, А. А. Курышев \\ Воронежский государственный университет
}

Поступила в редакцию 22 мая 2018 г.

\begin{abstract}
Аннотация: $\quad$ В статье проведена комплексная оценка состояния неоген-четвертичного водоносного комплекса юго-восточной части города Воронежа в соответствии с методами эколого-геологических исследований, интегральной оценкой трансформации подземных вод, а также построением трехмерных моделей дневной поверхности земли и подошвы неоген-четвертичного водоносного комплекса. В результате, состояние подземных вод исследуемого района оценивается как не соответствующее для ичелей питьевого водоснабжения. Площуадь загрязнения неогенчетвертичного водоносного комплекса в период 1992-2015 г2. варьирует от 18 до 22 км². Загрязнение подземных вод СПАВ является основной экологической проблемой изучаемого района. Выявлены все загрязняюшие вещзества неоген-четвертичного водоносного колплекса: натрий, бор, бром, СПАВ, железо, марганеи. Трехмерная модель дневной поверхности и подошвы неогенчетвертичного водоносного комплекса позволили выявить области аккумуляиии загрязняющих веществ: район бывших полей фильтрации, очистных сооружений, дач, иинного завода, завода Рудгормаш.
\end{abstract}

Ключевые слова: подземнье воды, содержание, СПАВ, СПЗ, питьевая вода, природные и техногенные факторы, качество питьевых вод.

\section{ECOLOGICAL-HYDROGEOCHEMICAL ESTIMATION OF THE CONDITION OF THE NEOGENE-QUARTERNARY WATERFALL COMPLEX OF THE SOUTH-EASTERN PART OF VORONEZH CITY}

\begin{abstract}
The article provides a comprehensive assessment of the state of the Neogene-Quaternary aquifer complex in the south-eastern part of the city of Voronezh in accordance with the methods of ecological and geological studies, an integrated assessment of the transformation of groundwater, and the construction of three-dimensional models of the day surface of the earth and the base of the Neogene-Quaternary aquifer complex. As a result, the groundwater status of the investigated area is estimated as not appropriate for drinking water supply purposes. The area of pollution of the Neogene-Quaternary aquifer complex in the period 1992-2015. varies from 18 to $22 \mathrm{~km} 2$. Pollution of groundwater is the main environmental problem of the studied area. All the pollutants of the Neogene-Quaternary aquifer complex were detected: sodium, boron, bromine, surfactants, iron, manganese. The three-dimensional model of the day surface and the basement of the Neogene-Quaternary aquifer complex made it possible to identify areas of accumulation of pollutants: the area of the former filtration fields, treatment facilities, dachas, tire plant, and the Rudgormash plant.
\end{abstract}

Key words: groundwater, content, surfactant, SDR, drinking water, natural and man-made factors, quality of drinking water.

\section{Введение}

В 30-хх годах прошлого столетия в СССР была реализована программа по строительству и вводу в эксплуатацию предприятий химической промышленности. Одним из крупнейших предприятий являлся завод по производству синтетических каучуков в городе Воронеже. За время его функционирования на окружающую среду было оказано значительное негативное воздействие. Дополнительным фактором ухуд- шения экологических параметров стало формирование промышленной зоны непосредственно вокруг предприятия.

Целью данного исследования является экологогидрогеохимическая оценка состояния неоген-четвертичного водоносного комплекса юго-восточной части города Воронежа.

Для достижения цели были поставлены следующие задачи: 
1) дать пространственно-временную оценку загрязнения подземных вод СПАВ;

2) дать пространственно-временную оценку загрязнения подземных вод всеми веществами по классам опасности;

3) построить трехмерную модель дневной поверхности земли и подошвы неоген-четвертичного водоносного комплекса для выявление выявления потенциальных областей аккумуляции загрязняющих веществ.

Район исследования располагается в юговосточной части города Воронежа, охватывая частный сектор в районе Песчановки, дачи, п. Никольское, п. Александровка и северную часть п. Масловка.

Изучаемая территория, начиная с 1930-хх, являлась промышленной зоной города, где происходило значительное воздействие на компоненты природной среды от ряда предприятий: АО «Воронежсинтезкаучук», АО «Воронежшина», АООТ «ВАСО» и др.

Актуальность исследования обуславливается наличием загрязнения СПАВ на протяжении более 50 лет, а также отсутствием комплексной экологогидрогеохимической оценки данной проблемы.

Одним из опасных загрязнений подземных вод юго-восточной части города Воронежа является загрязнение синтетическими поверхностно-активными веществами, в связи с длительностью существования данной проблемы, и безуспешностью попыток ликви- дации загрязнения [1].

Основными источниками поступления данного загрязнения являлись сброс промышленных стоков завода СК им. С. М. Кирова в поверхностные водотоки и на поля фильтрации.

\section{Методика исследований}

Оценка состояния неоген-четвертичного водоносного комплекса проводилась в соответствии со следующими методиками:

- эколого-гидрогеохимическая оценка состояния подземных вод (для оценки загрязнения подземных вод СПАВ рассчитывался коэффициент концентрации, а для оценки состояния по классам опасности рассчитывался СПЗ) [2];

- интегральная оценка трансформации подземных вод неоген-четвертичного водоносного комплекса по методике, разработанной И. И. Косиновой, Д. А. Белозеровым [3];

- построение трехмерной модели дневной поверхности земли и подошвы неоген-четвертичного водоносного комплекса для выявления потенциальных областей аккумуляции загрязняющих веществ в программном комплексе Surfer.

Оценка состояния подземных вод производилась по ассиметричной сети опробования, с увеличением числа наблюдательных скважин непосредственно у основных источников загрязнения (рис. 1).

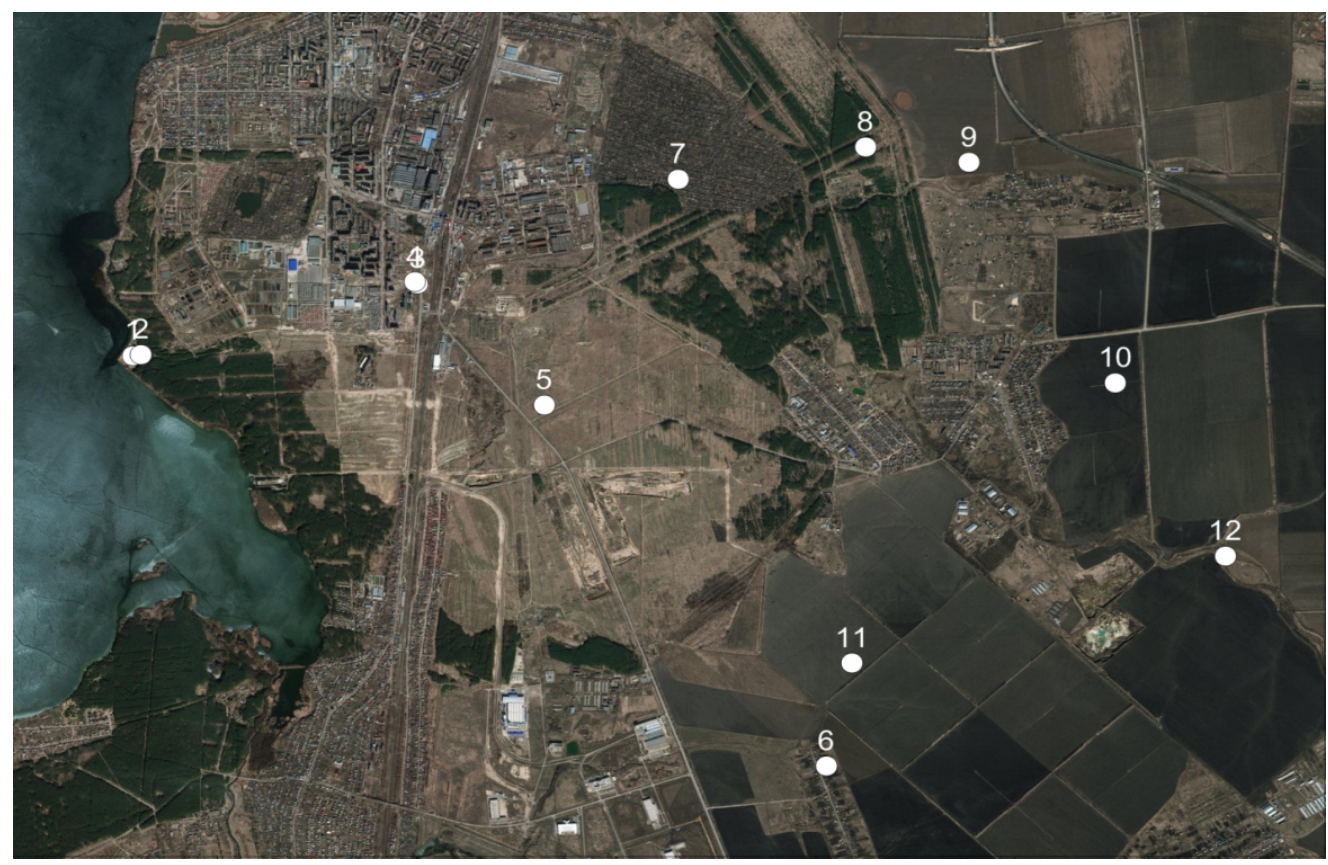

Pис. 1. Схема расположения скважин.

Для оценки степени загрязненности подземных вод хлорорганическими соединениями и другими веществами был использован параметр, имеющий взаимосвязь с экологической обстановкой. Этим параметром является: Кк - коэффициент концентрации по каждому элементу, превышающему ПДК, который рассчитывается по формуле [4]:

$$
K_{\mathrm{K}}=\frac{C_{i}}{C_{\text {пдк }}},
$$

где $C_{i}$ - концентрации элемента в анализируемой пробе (мг/дм ${ }^{3}, \mathrm{мг/кг);}$

$C_{\text {Пдк }}$ - нормируемая предельно допустимая концентрация данного элемента (мг/дм ${ }^{3}$, мг/кг) [5]. 
Суммарный показатель загрязнения рассчитывается по формуле:

$$
Z_{\mathrm{c}}=K_{k}-(n-1),
$$

где $\mathrm{n}$ - число загрязняющих веществ, по которым отмечается превышение ПДК.

Нормирование производилось согласно методам эколого-геологических исследований, отраженных в таблице 1.

Таблица 1

Нормирование состояния подземных вод по степени загрязнения СПАВ

\begin{tabular}{|c|c|c|}
\hline $\begin{array}{c}\text { Значения Кк } \\
\text { веществ 2 класса } \\
\text { опасности }\end{array}$ & $\begin{array}{c}\text { Значения Кк СПАВ } \\
\text { и веществ 3 класса } \\
\text { опасности }\end{array}$ & $\begin{array}{c}\text { Оценка } \\
\text { состояния } \\
\text { вод }\end{array}$ \\
\hline$<1$ & $<1$ & Допустимое \\
\hline $1-2$ & $1-5$ & $\begin{array}{c}\text { Уеренно } \\
\text { опасное }\end{array}$ \\
\hline $2-5$ & $5-10$ & Опасное \\
\hline $5-10$ & $10-15$ & $\begin{array}{c}\text { Высоко } \\
\text { опасное }\end{array}$ \\
\hline$>10$ & $>15$ & $\begin{array}{c}\text { Чрезвычайно } \\
\text { опасное }\end{array}$ \\
\hline
\end{tabular}

Определение уровней трансформации неогенчетвертичного водоносного комплекса проводилась в соответствии со следующим алгоритмом [3]:

1) Приведение степени защищенности подземных вод в баллы защищенности по формуле:

$$
\bar{S}_{3}{ }^{\prime}=\frac{25}{\bar{S}_{3}},
$$

где Бз - балл защищенности по Гольдбергу; Бз'приведенный балл защищенности;

2) Приведение СПЗ подземных вод в баллы СПЗ по формуле:

$$
C \Pi 3^{\prime}=\frac{(C \Pi 3+0,13)}{1,13},
$$

где СПЗ' - приведенный балл СПЗ, СПЗ - суммарный показатель загрязнения компонентов 3-4 класса опасности;

3) Расчет уровня трансформации водоносного комплекса :

$$
y_{\mathrm{T}}=C \Pi 3^{\prime}+E_{3}{ }^{\prime} .
$$

Уровни трансформации определяются согласно

\begin{tabular}{|c|c|c|c|}
\hline $\begin{array}{l}\text { Уровни трансформации } \\
\text { водоносного комплекса }\end{array}$ & $\begin{array}{c}\text { Расчетная величина (СП3') } \\
\text { (для 3,4-го классов опасности) }\end{array}$ & $\begin{array}{c}\text { Баллы } \\
\text { защищенности (Б3') }\end{array}$ & $\begin{array}{c}\text { Уровни трансформации } \\
\text { в баллах (Ут) }\end{array}$ \\
\hline Минимальный & СПЗ' $<1,0$ & $1 \leq$ Бз $<1,25$ & $1 \leq \mathrm{y}_{\mathrm{T}}<2,25$ \\
\hline Низкий & $1,0 \leq$ СПЗ' $<4,54$ & $1,25 \leq$ Б3 $<1,67$ & $2,25 \leq \mathrm{y}_{\mathrm{T}}<6,21$ \\
\hline Средний & 4,54 $\leq$ СПЗ’ $<8,96$ & $1,67 \leq$ Б3 ' $<2,50$ & $6,21 \leq \mathrm{y}_{\mathrm{T}}<11,46$ \\
\hline Высокий & $8,96 \leq$ СПЗ ' $<13,39$ & $2,50 \leq$ Б3 $3^{\prime}<5,00$ & $11,46 \leq \mathrm{y}_{\mathrm{T}}<18,39$ \\
\hline Максимальный & СПЗ’ $\geq 13,39^{\prime}$ & Б3' $\geq 5,00$ & $\mathrm{y}_{\mathrm{T}} \geq 18,39$ \\
\hline
\end{tabular}
таблице 2.

Таблица 2

Уровни трансформации

\section{Результаты исследований}

Оценка загрязнения подземных вод СПАВ показала результаты, систематизированные в виде схем на рисунке 2 и описанные ниже.

Так, в 1992 году ареал загрязнения поверхностно-

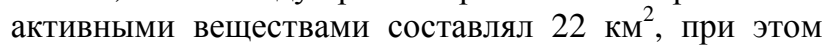
половину от площади очага загрязнения составляла область, превышающая ПДК в 15 раз и относящаяся к чрезвычайно опасному уровню загрязнения подземных вод. В эту область входят территория завода синтетических каучуков, очистных сооружений, частного сектора и северной части поселка Масловка. Область, относящаяся к высоко опасному уровню загрязнения, распространяется на восток, загрязненные воды подтягивает здесь водозабор Шинного завода. В целом, наблюдается распространение области загрязнения по направлению к действующим водозаборам.

Помимо большой пространственной области загрязнения, хлорорганические соединения оказывают влияние и по глубине, затрагивая как неоген- четвертичный водоносный комплекс, так и девонский. С глубиной происходит увеличение концентрации загрязнения. Для неоген-четвертичного водоносного комплекса в 1992 году концентрация СПАВ на глубине 24,8 м составила около 2 мг/л, тогда как на глубине 78,8 м достигала 9,6 мг/л. В девонском водоносном комплексе также наблюдается увеличение содержания СПАВ с 10 мг/л на глубине 29,7 м до 15 мг/л на глубине 36,7 м. Пониженные концентрации в верхнем интервале можно объяснить оседанием загрязнения и его аккумуляцией на глубине, разбавлением за счет инфильтрации атмосферных осадков, а также конвективным переносом, т.е. скоростью и направлением естественного потока подземных вод и действием водозаборов.

По данным химического анализа проб, отобранных в 2002 году, можно проследить улучшение сложившейся экологической ситуации. Концентрации хлорорганических веществ снижаются и уже не превышают 10 ПДК. 

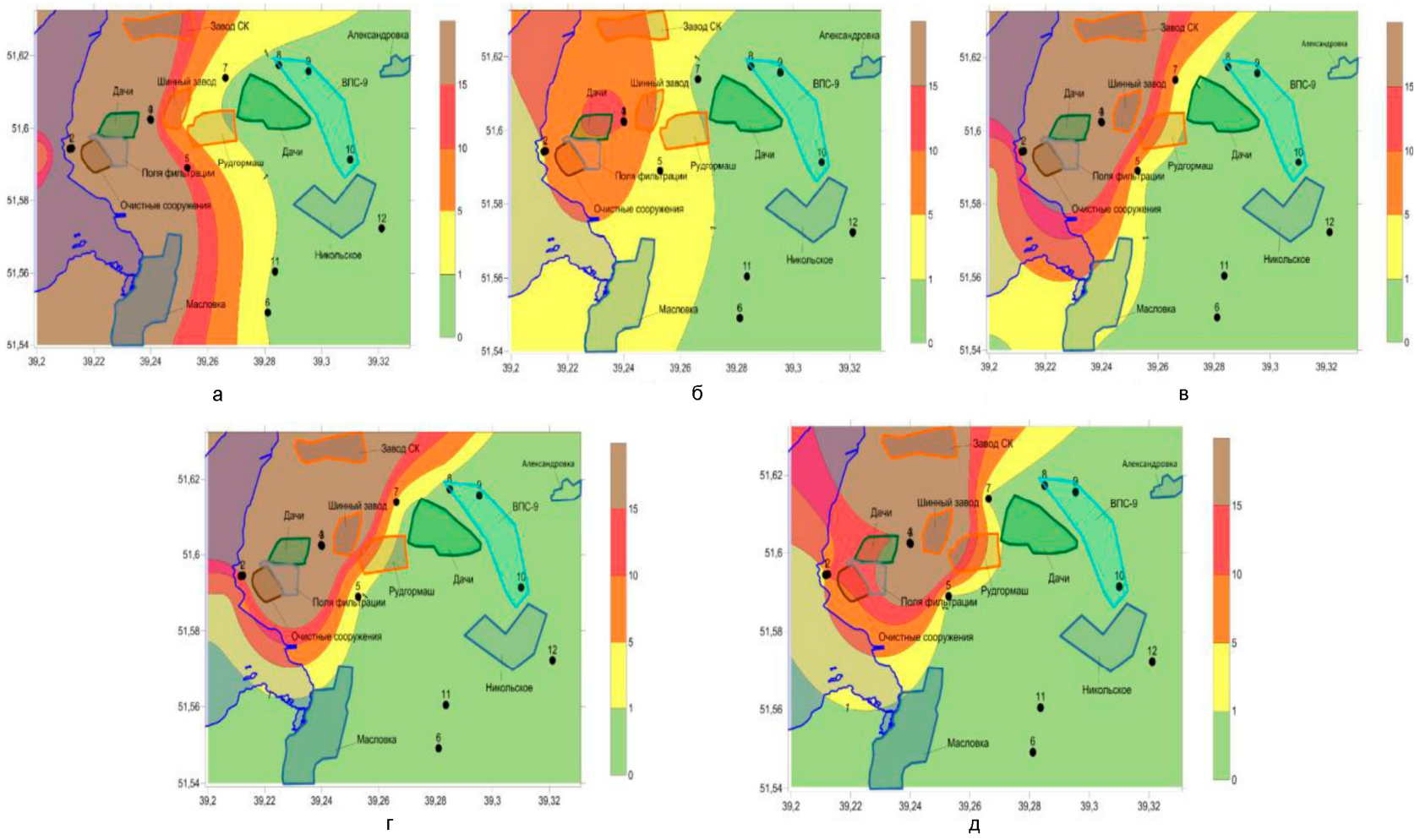

Pис. 2. Схемы распределения коэффициента концентрации СПАВ в долях ПДК по годам: $a-1992$ г.; 6 - 2002 г.; 6 - 2011 г.; г-2013 г.; $\partial-2015$ г.

Основная область загрязнения расположена на северо-западе карты и затрагивает поля фильтрации, завод СК, часть Шинного завода, очистных сооружений и частного сектора. В 2002 году общая площадь загрязнения снизилась на $3 \mathrm{kм}^{2}$ и составила $19 \mathrm{kм}^{2}$. Чрезвычайно опасная зона загрязнения отсутствует, наблюдается значительное снижение концентраций хлорорганических соединений с первых сотен мг/л до единиц. Площадь высоко опасной зоны также сокращается, и имеет тенденцию распространения к основным действующим водозаборам. Опасная область загрязнения распространяется по направлению к водозабору № 6. Умерено опасная зона загрязнения охватывает большую территорию, включающую в себя часть завода синтетических каучуков, Рудгормаш и северную часть п. Масловка.

Значительное улучшение в плане и по глубине связано с активной работой барражного водозабора. Реабилитационные работы активно начали проводиться с 1984 года и продолжались до 2001 года, но, несмотря на все улучшения, работы не достигли полного эффекта. Дебит водозабора соответствовал максимальной способности очистных сооружений.

В связи с прекращением реабилитационных работ и остановкой эксплуатации барражных скважин, в 2011 году снова наблюдается значительное ухудшение обстановки с увеличением площади загрязнения. Снова возникает зона чрезвычайно опасного содержания хлорорганических соединений, превышающих 15 ПДК. Площадь загрязнения в 2011 г составляет 20 км² $^{2}$ В 2013 не наблюдается значительных изменений в структуре и площади очага загрязненных подземных вод, пространственное положение остается тем же и направлено в сторону разгрузки вод и к водозаборам, подходя в плотную к 9 водозабору. Чрезвычайно опасная зона загрязнения остается прежней с максимальными значениями в 4 скважине 62,5 мг/л, что превышает ПДК в 125 раз. Такое содержание хлорорганических соединений пространственно располагается вблизи бывшего водозабора Шинного завода и ЖБИ-5 и говорит о том, что изначальный очаг, находившийся в районе полей фильтрации, распространяется в плане. Общая площадь загрязнения составляет

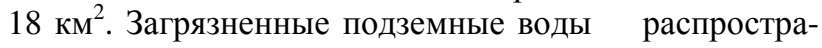
нились к водохранилищу.

В 2015 годуоду ситуация остается прежней, общая площадь загрязнения составляет 18 км². Для чрезвычайно опасной зоны загрязнения подземных вод характерно смещение области в северо-восточном направлении к бывшему водозабору Шинного завода и водозабору № 9, возможно это связано с увеличением максимально допустимого водопотребления на водозаборе № 9. Поскольку в непосредственной близости от основного очага загрязнения находятся частный сектор и дачи с отсутствующим централизованным водоснабжением, то миграция СПАВ также связана с активным водопотреблением жителями указанных территорий. Общая направленность загрязнения с северо-запада на юго-восток остается неизменной, как и увеличение концентрации поверхностно-активных веществ с глубиной. В 2015 году максимальное значение содержания хлорорганических соединений бы- 
ло обнаружено в 4 скважине и составляло 44 мг/л, что превышает предельно допустимую концентрацию для данного элемента в 88 раз.

По построенной диаграмме площадей (рис. 3) загрязнения можно сделать вывод об относительной неизменности общей площади загрязнения хлорорганическими соединениями.

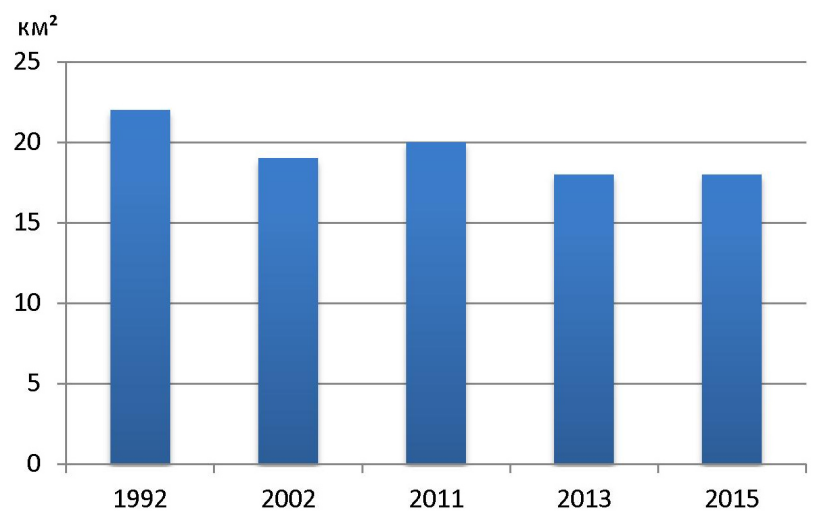

Рuc. 3. Площади загрязнения подземных вод СПАВ по годам в км².

Если для всей области загрязнения СПАВ характерна общая неизменность площади, то для каждого класса опасности она различна, из чего можно сделать вывод об изменении концентрации загрязняющего вещества. Помимо высоких концентраций СПАВ в неоген-четвертичном комплексе, повышенные его содержания наблюдаются и в девонском комплексе.

Максимальная концентрация загрязнения была зафиксирована в 1992 году - 51 мг/л, что превышает ПДК в 100 раз, в связи с работой барражных скважин концентрацию к 2002 году удалось понизить до 7,53 мг/л, что превышает ПДК в 5 раз. В 2007 г. и в 2014 г. наблюдаются очередные пики загрязнения, которые, возможно, связаны с увеличением объема производства.

По наблюдательным скважинам, которые находятся ближе всего к источникам загрязнения подземных вод, была оценена динамика концентраций СПАВ по годам (рис. 4). Анализ трех диаграмм (скважины, пробуренные для контроля неоген-четвертичного водоносного комплекса и девонского водоносного комплекса) позволил выделить 3-и этапа загрязнения подземных вод:

1 этап - с 1982 по 1992 год характеризуется чрезвычайно опасным уровнем загрязнения неоген-четвертичного и девонского водоносных комплексов. Концентрации СПАВ варьировали в широком диапазоне от 200 мг/л (400 ПДК) до 8 мг/л (16 ПДК);
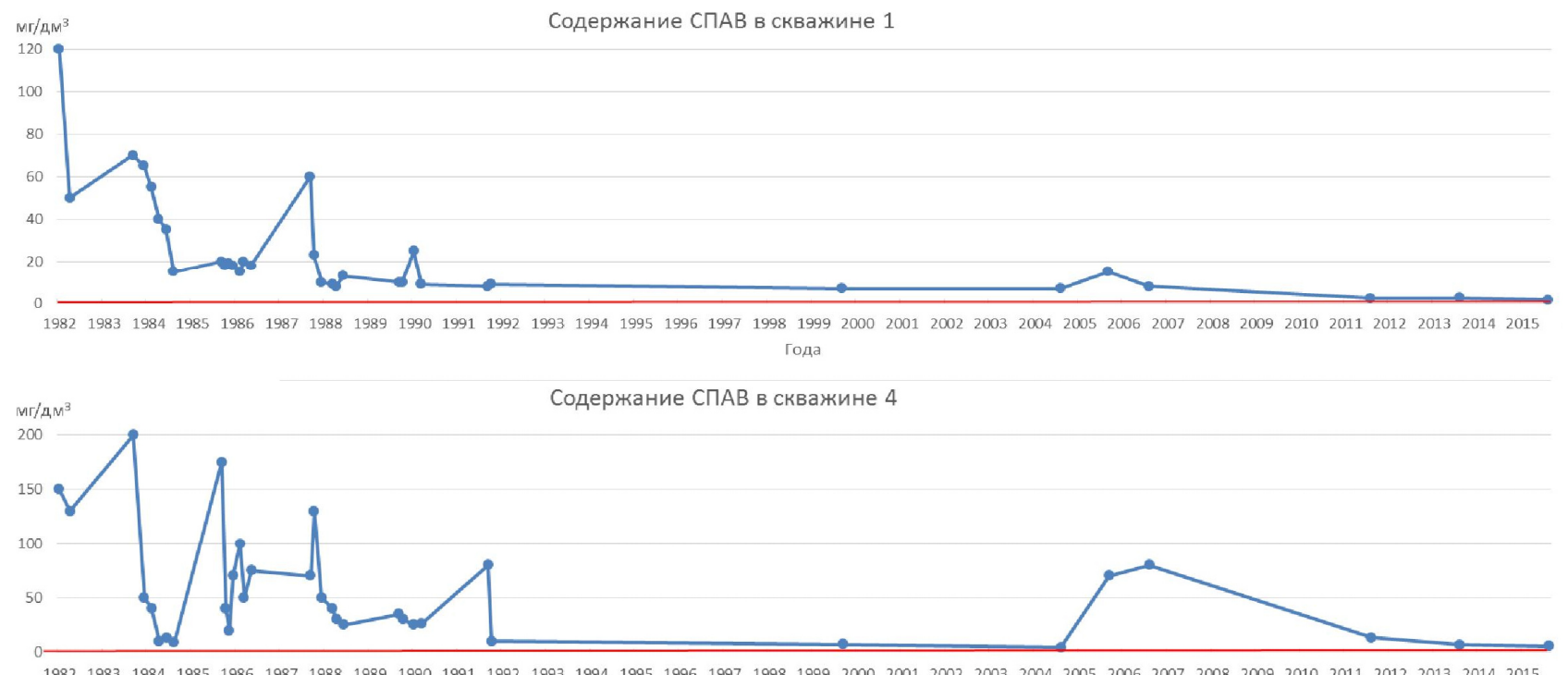

1982198319841985198619871988198919901991199219931994199519961997199819992000200120022003200420052006200720082009201020112012201320142015 года

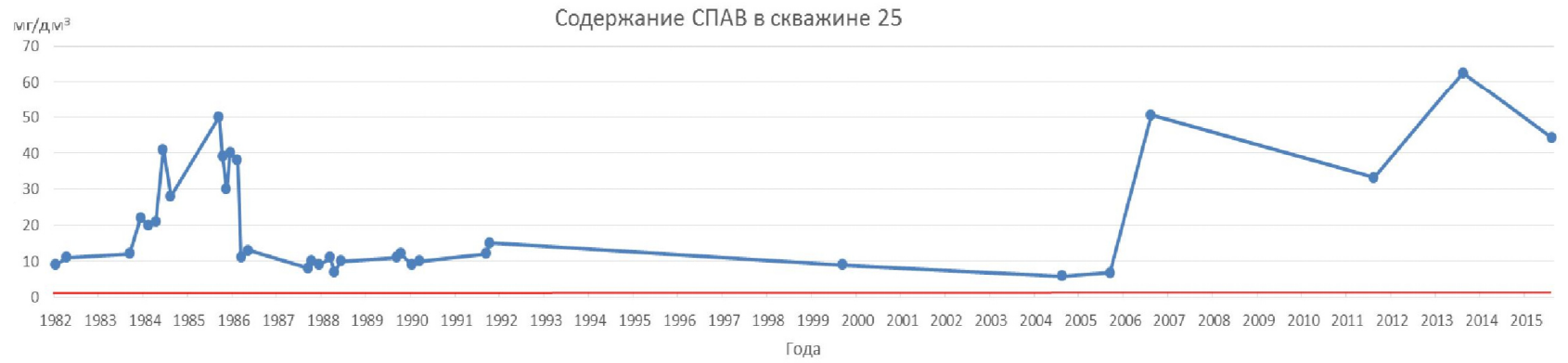

Puc. 4. Динамика изменения концентрации СПАВ в скважинах неоген-четвертичного (две верхние диаграммы) и девонского комплексов (нижняя диаграмма). 
2 этап - с 1992 по 2004 год характеризуется снижением загрязнения подземных вод СПАВ до первых единиц (2ПДК), стабильной динамикой. Это связано с работой барражных скважин и снижением объема производства предприятий химической промышленности.

3 этап - с 2005 года по 2015 года характеризуется резким «скачком» концентрации хлорорганических соединений до более чем 70 мг/л (140 ПДК) и их последующим постепенным снижением, что связано с увеличением производственных мощностей. Уровень загрязнения СПАВ подземных вод неоген-четвертичного и девонского водоносных комплексов попрежнему остается чрезвычайно высоким, т.е. превышает 15 ПДК.

Расчет суммарного показателя загрязнения в 2011
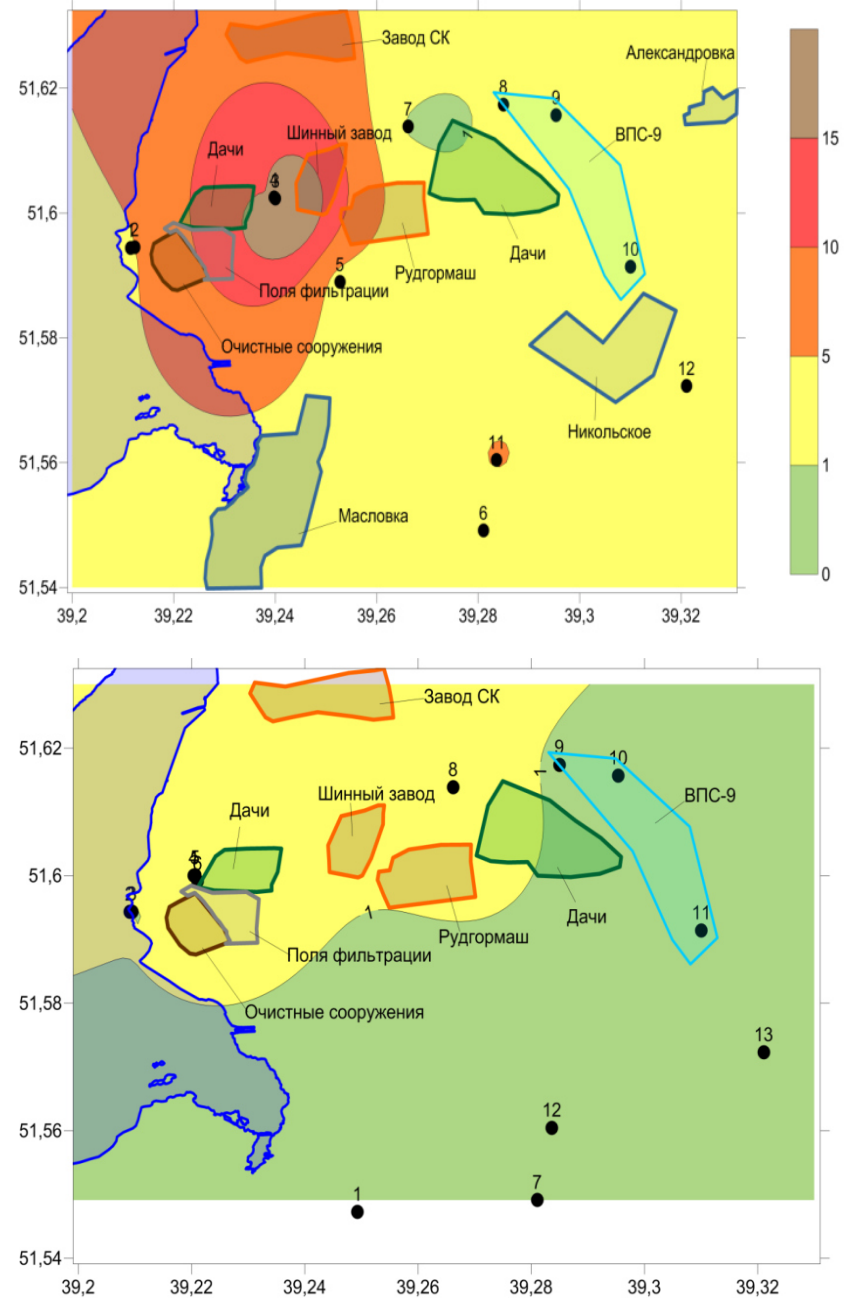

Масштаб загрязнений подземных вод элементами 3 и 4 классов опасности носит практически повсеместный характер, охватывая как техногенно нагруженные территории, так и территории, не имеющие активного влияния со стороны деятельности человека. Основными загрязняющими веществами 3-4 класса опасности являются железо и марганец.

Основные загрязняющие вещества юго-восточной части г. Воронежа с учетом класса опасности пере- и 2015 годах по классам опасности является следующей задачей настоящего исследования. В 2011 году загрязнений веществами 1 и 2 класса опасности не выявлено. В 2015 году наблюдается загрязнение подземных вод элементами второго класса опасности. Загрязнение относится к умеренно опасному уровню, то есть содержание веществ второго класса опасности не превышает двух ПДК и приурочено к размещению промышленных объектов, таких как: биологические очистные сооружения, бывшие поля фильтрации, Шинный завод и завод СК, а также завод Рудгормаш. Основными элементами 2 класса опасности, формирующими очаг загрязнения, являются бром, бор и натрий. Характер загрязнений преимущественно техногенный и связан с основными объектами химической промышленности (рис. 5).

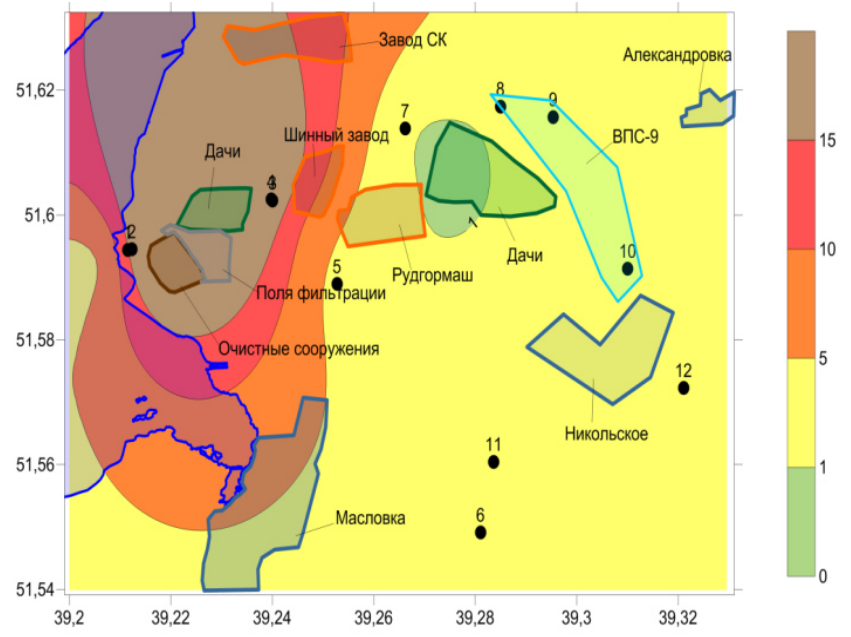

Puc. 5. Карта суммарного показателя загрязнения по 34 классам опасности за 2011 и 2015 гг (вверху) и по 2 классу опасности за 2015 г (внизу).

числены в таблице 3.

Структура загрязняющих веществ и их вклад в суммарный показатель загрязнения, без учета синтетических поверхностно-активных веществ, приведен в таблице 4. Основным загрязняющим компонентов компонентом из веществ 2 класса опасности является натрий, а из веществ 3 класса опасности - железо (без учета СПАВ).

Следующей задачей проведенных исследований 
Таблица 3

Основные загрязняющие вещества и их классы опасности

\begin{tabular}{|c|c|}
\hline Вещество & Класс опасности \\
\hline натрий & 2 \\
\hline бор & 2 \\
\hline бром & 2 \\
\hline железо & 3 \\
\hline марганец & 3 \\
\hline СПАВ & 4 \\
\hline
\end{tabular}

является построение трехмерной модели дневной поверхности земли и подошвы неоген-четвертичного водоносного комплекса для выявление выявления потенциальных областей аккумуляции загрязняющих веществ в программном комплексе Surfer (рис. 6).

На участках с пониженным рельефом располагаются: поля фильтрации, очистные сооружения, дачный сектор и заводы: Рудгормаш и Шинный. Из-за того, что бывшие поля фильтрации находятся в понижении, то происходит постоянное увеличение загрязнения хлорорганическими соединениями подземных вод хлорорганическими соединениями, также загрязненные воды с заводов могут попадать в эту область.

Траектория стока воды имеет юго-западную ориентированность и направлена в сторону водохранилища. На повышенных участках расположены: ВПС-9, частный сектор, завод Рудгормаш и Шинный. Из-за такого расположения возможно снижение качества вод, попадающих в водохранилище с поверхностным стоком.

Таблица 4

Доля загрязняющих веществ в суммарном показателе загрязнения

\begin{tabular}{|c|c|c|c|}
\hline Вещество & $\begin{array}{c}\text { Доля загрязняющих веществ 2 } \\
\text { класса опасности в структуре } \\
\text { СП3 в 2015 году }\end{array}$ & $\begin{array}{c}\text { Доля загрязняющих веществ 3 } \\
\text { класса опасности в структуре } \\
\text { СП3 в 2013 году }\end{array}$ & $\begin{array}{c}\text { Доля загрязняющих веществ 3 } \\
\text { класса опасности в структуре } \\
\text { СП3 в 2015 году }\end{array}$ \\
\hline Натрий & $39 \%$ & - & - \\
\hline Бор & $27 \%$ & - & - \\
\hline Бром & $34 \%$ & - & - \\
\hline Железо & - & $75 \%$ & $26,4 \%$ \\
\hline Марганец & - & $25 \%$ & \\
\hline
\end{tabular}
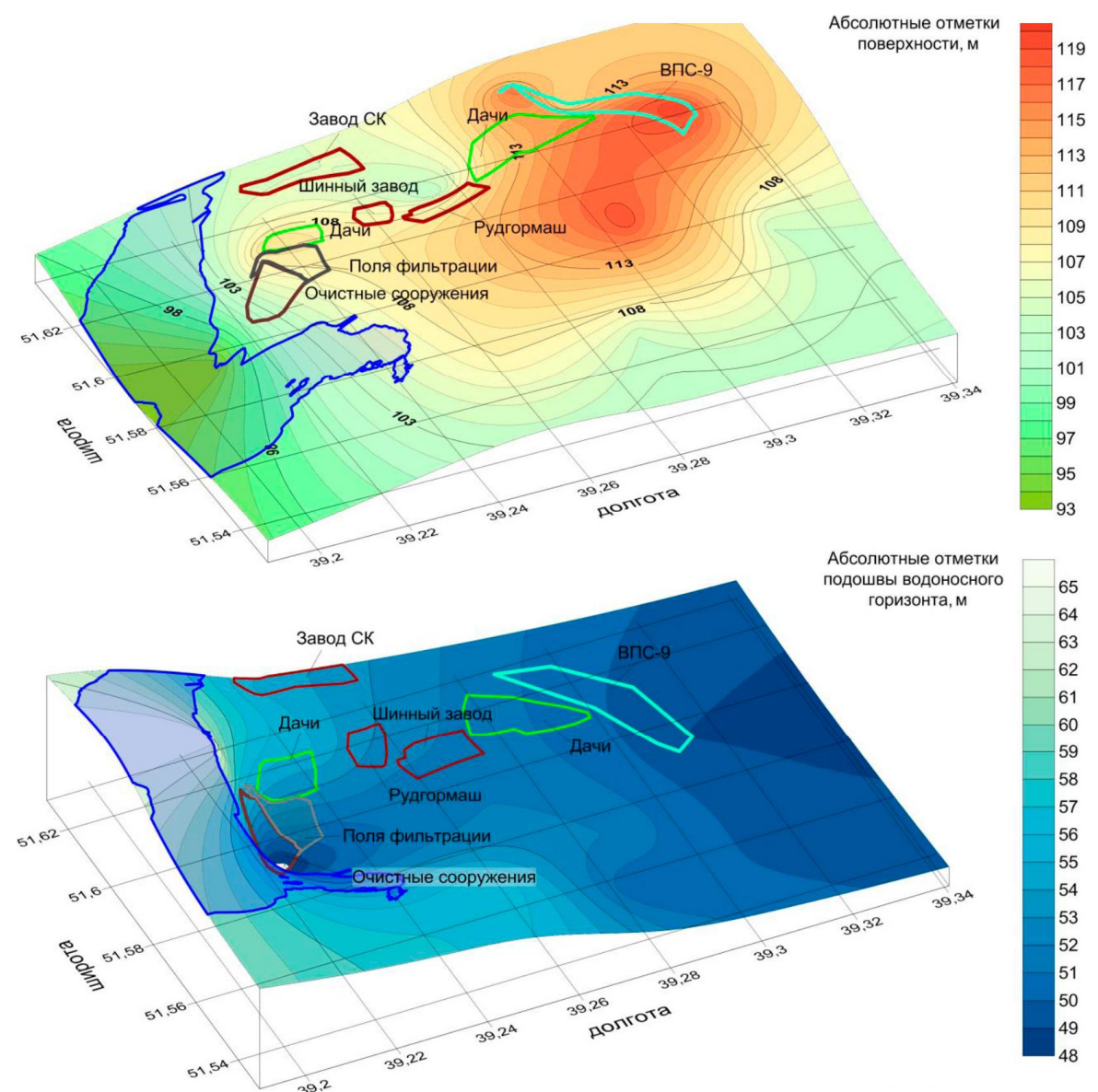

Puc. 6. 3-D модель дневной поверхности и подошвы водоносного неоген-четвертичного комплекса. 
В пониженных участках подошвы неоген-четвертичного водоносного комплекса, в районе бывших полей фильтрации, очистных сооружений, дач, шинного завода, завода Рудгормаш возможно накопление и аккумуляция СПАВ. Также пониженный участок наблюдается в районе ВПС-9 и далее на восток, что обуславливает возможность накопления загрязненных вод в данных районах. В соответствии с проведенной интегральной оценкой трансформации подземных вод, максимальный уровень наблюдается в области очистных сооружений, бывших полей фильтрации, Шинного завода и завода синтетических каучуков (рис. 7).

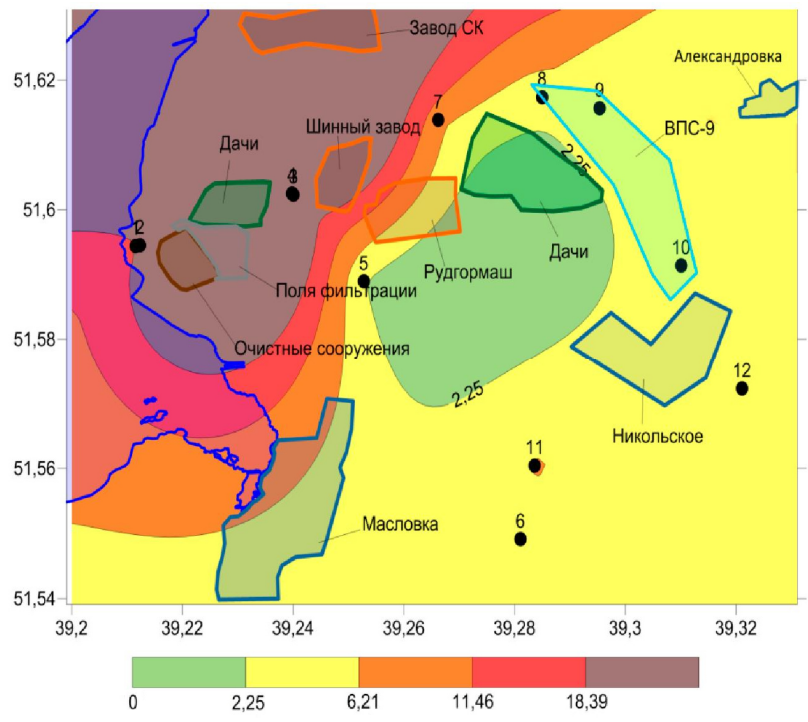

Pис. 7. - Оценка трансформации подземных вод.

Это обусловлено рядом факторов:

1) близостью основного источника загрязнения подземных вод;

2) низкой степенью защищенности водоносного комплекса;

3) относительно низкими абсолютными отметками дневной поверхности;

4) относительно низкими абсолютными отметками подошвы неоген-четвертичного водоносного комплекса;

5) длительностью негативного воздействия со стороны предприятий химической промышленности.

\section{Заключение}

В результате проведенных исследований была дана эколого-гидрогеохимическая оценка состояния

\section{Воронежский государственный университет} Белозеров Денис Александрович, кандидат географических наук, дочент кафедры экологической геологии E-mail: belozerovdenis@yandex.ru; Tел.: 89038507664 Летникова Анастасия Сергеевна, магистрант кафедры экологической геологии. E-mail: rebel444@yandex.ru Курышев Александр Александрович, к. г.-м. н., доцент кафедры экологической геологии

E-mail: kaa@geol.vsu.ru; Teл.: 8-473-220-82-89 неоген-четвертичного водоносного комплекса юговосточной части города Воронежа.

В целом, состояние подземных вод оценивается как не соответствующее для целей питьевого водоснабжения. Площадь загрязнения неоген-четвертичного водоносного комплекса в период 1992-2015 гг.

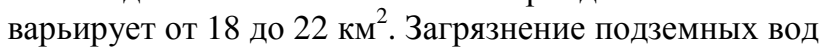
СПАВ является основной экологической проблемой изучаемого района на протяжении всего рассматриваемого периода. Выделяется три этапа загрязнения подземных вод СПАВ.

Выявлены все загрязняющие вещества неогенчетвертичного водоносного комплекса: натрий, бор, бром, СПАВ, железо, марганец.

Трехмерная модель дневной поверхности и подошвы неоген-четвертичного водоносного комплекса позволили выявить области аккумуляции загрязняющих веществ: район бывших полей фильтрации, очистных сооружений, дач, шинного завода, завода Рудгормаш.

Исходя из проведенных исследований, можно сделать вывод о крайней необходимости реабилитационных работ в районе очага загрязнений, запуска барражных скважин, реорганизации системы наблюдательных скважин и контроля загрязнения на региональном уровне.

\section{ЛИТЕРАТУРА}

1. Косинова, Ирина И. ИвановнаИ. Оценка загрязнения подземных вод синтетическими поверхностно-активными веществами в юго-восточной части Воронежа / И. И. Косинова, Д. А. Белозеров, В. В. Дорофеев // Инженерные изыскания : всероссийский научно-аналитический журнал .- . . Москва, 2017 .- . .№ 5. - С. 28-35 .- ISSN 1997-8650.

2. Белозеров, Д. А. Микрокомпонентный анализ качества подземных вод южной части левого берега города Воронежа / Д. А. Белозеров // Вестник Воронеж. гос. ун-та. Сер.: Геология. Вестник Воронежского государственного университета. Сер. Геология .- Воронеж, 2017 .- - . - № 1. - - С. 130-134.

3. Косинова, И. И. Методика оценки трансформации верхних водоносных горизонтов в зоне влияния предприятий по производству минеральных удобрений / И. И. Косинова, Д. А. Белозеров // Труды НИИ геологии Воронеж. гос. ун-та. - Вып. 84 Воронеж. - 2014. - $121 \mathrm{c}$.

4. Косинова, И. И. Методы эколого-геохимических, экологогеофизических исследований и рациональное недропользование: учебное пособие для студ. вузов, обуч. по направлению 511000 "Геология" и университетским геол. специальностям / И. И. Косинова, В. А. Богословский, В. А. Бударина. - Воронеж : Изд-во гос. ун-та. - 2004. - 279 с.

5. Санитарно-эпидемиологические правила и нормативы. СанПиН 2.1.4.1074.01 «Питьевая вода. Гигиенические требования к качеству воды централизованных систем водоснабжения. Контроль качества». - Госкомэпиднадзор России. - М. - 2002 г.

Voronezh State University

Belozerov D. A., Candidate of Geographical Sciences, Associate professor of Ecological Geology Department

E-mail: belozerovdenis@yandex.ru; Tel.: 89038507664

Letnikova A. S., Master of the Ecological Geology Department

E-mail: rebel444@yandex.ru; Tel.: 89103417439

Kuryshev A. A., Candidate of Geological and Mineralogical Sciences, Associate professor of Ecological Geology Department. E-mail: kaa@geol.vsu.ru; Tel.: 8-473-220-82-89 